\title{
Mental Health Status among Adolescents of High Schools: A Cross-sectional Study
}

\author{
- *Baishali Dass ${ }^{1} \bullet$ *Binita Kandangwa² • Rita Pokharel ${ }^{3}$
}

Submitted 1 January 2021

Đ Rita Pokharel

rita.pokharel@bpkihs.edu

(iD https://orcid.org/0000-0001-5873-4638

1 Staff Nurse

${ }^{3}$ Department of Psychiatric Nursing, B. P. Koirala Institute of Health Sciences, Dharan, Nepal.

2 Field Enumerator, New ERA, Kathmandu, Nepal

* contributed equally

\section{Citation}

"Dass B, Kandangwa B, Pokharel R. Mental health status among adolescents of high schools: A cross-sectional study. JBPKIHS. 2021;4(1):4-8.

\section{doi https://doi.org/10.3126/jbpkihs.v4i1.33982}

\section{(c) (1) $(9)$}

This work is licensed under a Creative Commons Attribution NonCommercial 4.0 International License.
Accepted 10 May 2021

Published 30 June 2021

Background: Adolescents are prone to develop various psychosocial problems with a long-standing impact. We aimed to investigate the mental health status among adolescents from high schools in Dharan sub-metropolitan city.

Methods: In this descriptive cross-sectional study, we enrolled 150 adolescents from two different schools of Dharan, using a stratified random sampling technique. The Pediatric Symptoms Checklist for Youth was used to assess their mental health status. A score of 30 or more was considered as a mental health problem. Poverty, family dispute, punishment, and personal and family history of a psychiatric condition were considered as potential predictors of mental health problem. The chi-square test was applied to identify the predictors of mental health problem.

Results: The final analysis included I4I samples. More than $60 \%$ of the students belonged to the age group $13-15$ years, and $52.5 \%$ were females. About $59.6 \%$ were Janajatis, and $61 \%$ were Hindus. The majority $(63.8 \%$ ) were living below the poverty line. The majority ( $83.7 \%$ ) had no dispute in the family. All the students had received punishment, and $51.1 \%$ had received it at home. One-third of the students had mental health problem. The presence of mental health problem was significantly associated with nuclear family status $(p=$ $0.04)$, and history of a family dispute $(p=0.04)$.

Conclusion: Mental health problem was common among adolescents, and it was associated with the nuclear family structure and the presence of family dispute.

Keywords:Adolescent, Mental Health, School

\section{Declarations}

Ethics approval and consent to participate: Ethical approval was obtained from Departmental Research Unit, College of Nursing, BPKIHS (Ref No. - CON-224/075/076), and written informed consent was taken from parents of all the participants.

Consent for publication: Not applicable

Availability of data and materials: Full data set supporting this research

will be available from the principal investigator on request.

Competing interest: None

Funding: None
Authors' contributions: BD and BK: design, data acquisition, analysis, manuscript review. RP: design, manuscript preparation editing.All the authors have read and approved the final manuscript.

Acknowledgement: We would like to thank all the participant schools and students. 
$\mathrm{A}$ dolescence, age between 10 and 19 years, is a transition phase from a "child" into an "adult" [1]. It is a formative and crucial period demanding significant adjustment to the physical, psychological, and social changes [1]. Adolescents are vulnerable to psychosocial problems such as behavioral, emotional, and educational problems [2]. Mental health problems affect $10-20 \%$ of children and adolescents worldwide, accounting for 15$30 \%$ of disability-adjusted life years during the first three decades of life [3]. Failure to recognize and address mental health problem among adolescents is a serious public health concern. Screening mental health status in adolescents is a very important step for early detection and timely intervention. This study aimed to find out the mental health status in adolescents of high schools of Dharan sub-metropolitan city and identify its predictors.

\section{METHODS}

$\mathrm{A}^{\mathrm{t}}$ fter obtaining approval from the Departmental Research Unit, College of Nursing, B. P. Koirala Institute of Health Sciences for this cross-sectional study, we enrolled students from classes 9 and 10 in Dharan sub-metropolitan city, located in the Province 1 of eastern Nepal. All the 22 high schools located in different wards/ subunits of the city were stratified into private $(n=12)$ and government $(n=10)$ schools. One school from each stratum was selected randomly by lottery method. The total number of students from class 9 and 10 in each selected private and government schools were 114 and 184, respectively. After obtaining consent from parents, 58 students from the selected private school and 92 students from the selected government school were enrolled randomly. The sample size of 150 was estimated considering the prevalence of $41.4 \%$ [4], 95\% confidence interval and $80 \%$ power with the non-response rate of $10 \%$.

For socio-demographic data, a semi-structured questionnaire was used. The Pediatric Symptom Checklist for Youth (PSC-Y) tool, a self-response questionnaire, was used to assess the mental health status [5]. The tool was translated into the Nepali language. Translation and back-translation were performed by consulting language experts.

The PSC-Y is a psychosocial screening tool designed to facilitate the recognition of cognitive, emotional, and behavioral problems in adolescents aged 11 and above. It consists of 35 items that are rated as "never", "sometimes" or "often" present and scored as $\mathrm{o}, 1$ and 2, respectively. The total score is calculated by adding together the scores for each of the 35 items. The items left blank are scored as o. If four or more items are blank, the questionnaire is considered invalid. A score of 30 or higher indicates significant psychological impairment indicating the presence of psychosocial problem, and thus mental health problem.

Poverty was categorized with the help of the absolute poverty line defined by the World Bank in 2015; less than 1.90 USD per capita per day [6]. Any dispute between parents or dispute among family members were considered as having a family dispute. Corporal punishment was considered as punishment. Students undergoing treatment or consultation for mental health issues were considered as having history of psychiatric problem. Presence of any psychiatric condition in the first or second-degree relatives was considered as family history of psychiatric problem.

The data was entered in Microsoft Excel spread sheet and transferred into Statistical Package for Social Sciences version 16.5 (SPSS Inc; Chicago, IL, USA) for statistical analysis. The data was summarized using frequency distribution tables. The chi-square test was used to identify the predictors of the mental health problem. The probability of significance was set at $5 \%$ and confidence interval at $95 \%$.

\section{RESULTS}

f the 150 questionnaires distributed, 5 were not returned and 4 were incomplete. So, a total of 141 responses were included for the final analysis. The age of the participants (mean \pm SD) was $15.2 \pm 1.1$ years. Psychosocial problem was present in $33 \%$ of adolescent students (Fig. 1).

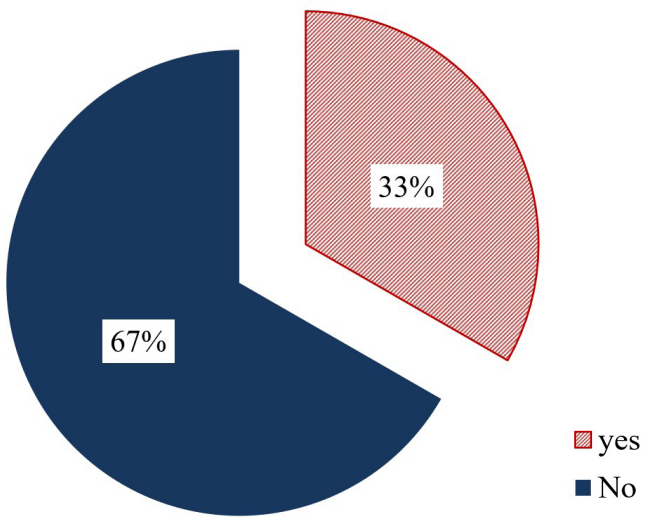

Figure 1: Psychosocial Problems among respondents. $(n=141)$ 


\begin{tabular}{|c|c|c|c|c|}
\hline \multirow[t]{2}{*}{ Characteristics } & \multirow[t]{2}{*}{ Category } & \multicolumn{2}{|c|}{ Mental Health Problem } & \multirow[t]{2}{*}{$p$-value } \\
\hline & & No & Yes & \\
\hline \multirow[t]{2}{*}{ Age (years) } & $13-15(n=85)$ & 61 & 24 & \multirow{2}{*}{0.11} \\
\hline & $16-18(n=56)$ & 33 & 23 & \\
\hline \multirow[t]{2}{*}{ Gender } & Male $(n=67)$ & 50 & 17 & \multirow{2}{*}{0.06} \\
\hline & Female $(n=74)$ & 44 & 30 & \\
\hline \multirow[t]{2}{*}{ Ethnicity } & Janajati $(n=84)$ & 57 & 27 & \multirow{2}{*}{0.72} \\
\hline & Others $(n=57)$ & 37 & 20 & \\
\hline \multirow[t]{2}{*}{ Religion } & Hindu $(n=86)$ & 55 & 31 & \multirow{2}{*}{0.39} \\
\hline & Others $(n=55)$ & 39 & 16 & \\
\hline \multirow[t]{2}{*}{ Type of school } & Government $(n=89)$ & 62 & 27 & \multirow{2}{*}{0.32} \\
\hline & Private $(n=52)$ & 32 & 20 & \\
\hline \multirow[t]{2}{*}{ Class } & Nine $(n=57)$ & 33 & 24 & \multirow{2}{*}{0.07} \\
\hline & Ten $(n=84)$ & 61 & 22 & \\
\hline \multirow[t]{2}{*}{ Type of family } & Nuclear $(n=79)$ & 47 & 32 & \multirow{2}{*}{0.04} \\
\hline & Joint $(n=62)$ & 47 & 15 & \\
\hline \multirow[t]{2}{*}{ Education of father } & High school and above $(n=69)$ & 49 & 20 & \multirow{2}{*}{0.28} \\
\hline & Others $(n=72)$ & 45 & 27 & \\
\hline \multirow[t]{2}{*}{ Education of mother } & High school and above $(n=46)$ & 32 & 14 & \multirow{2}{*}{0.61} \\
\hline & Others $(n=95)$ & 62 & 33 & \\
\hline \multirow[t]{4}{*}{ Occupation of father } & Business/Service $(n=29)$ & 17 & 12 & \multirow{4}{*}{0.46} \\
\hline & Unskilled work $(n=68)$ & 44 & 24 & \\
\hline & Foreign employee $(n=23)$ & 18 & 5 & \\
\hline & Others $(n=21)$ & 15 & 6 & \\
\hline \multirow[t]{2}{*}{ Poverty } & Below poverty line $(n=90)$ & 59 & 31 & \multirow{2}{*}{0.14} \\
\hline & Above Poverty line $(n=5 I)$ & 35 & 16 & \\
\hline \multirow[t]{2}{*}{ Occupation of mother } & Homemaker $(n=94)$ & 61 & 33 & \multirow{2}{*}{0.53} \\
\hline & Others $(n=47)$ & 33 & 14 & \\
\hline Family dispute & Yes $(n=2 I)$ & 10 & 11 & 00 \\
\hline & No $(n=120)$ & 84 & 36 & 0.04 \\
\hline Received punishment & Home $(n=72)$ & 52 & 20 & \\
\hline & School $(n=29)$ & 20 & 9 & 0.17 \\
\hline & Home and school $(n=40)$ & 22 & 18 & \\
\hline History of psychiatric problem & Yes $(n=8)$ & 4 & 4 & 0 \\
\hline & No $(n=133)$ & 90 & 43 & 0.44 \\
\hline Family history of psychiatric problem & Yes $(n=21)$ & 12 & 9 & ריר \\
\hline & No $(n=120)$ & 82 & 38 & 0.52 \\
\hline
\end{tabular}

Most of the adolescents lived in a nuclear family (56\%) and below the poverty line (63.8\%), with the per capita income (mean \pm SD) of $1.29 \pm 0.95$ USD. More than half of the adolescents received punishment at home. Respondents from nuclear family and those who witnessed any family dispute had significantly high levels of mental health problem (Table 1).

\section{DISCUSSION}

Tn this descriptive cross-sectional study, we found that one-third of the adolescents from high schools of Dharan sub-metropolitan city had mental health problems. More students from nuclear families and those with family disputes had mental health problems. 
More than half of our adolescent students (52.5\%) were females. Similar studies with more females in the study population have been performed in central Nepal and eastern Finland $[7,8]$. More than $60 \%$ of our students were Hindus. A similar study from central Nepal had $88.5 \%$ of Hindu students [7]. According to the 2011 census, Hindu is the major religion (81.3\%) in Nepal [9]. As per government data of Nepal, a higher proportion of Janajatis inhabit in the central and eastern parts. About $60 \%$ of our study population belonged to the Janajati ethnic group [10]. A study in Kathmandu also reported a similar finding [11]. The majority of the adolescents' parents were literate, which is comparable to the finding of a study done in Kathmandu [11]. Nearly $45 \%$ of our adolescents' mothers had education till primary level. Half (48.2\%) of the adolescents' fathers were unskilled workers and the majority of the mothers were homemakers. A study done in Kathmandu showed that the majority (71.3\%) of the adolescents' fathers were farmers and nearly half of the adolescents' mothers (48.8\%) were homemakers [11].

In this present study, the majority of the adolescents $(63.8 \%)$ were below the poverty line. About one-quarter of Nepalese population live below the poverty line [10]. This study assessed poverty in terms of cash. However, other related areas of income (agriculture and fixed assets) were not assessed. Therefore, the estimation could have been overinflated. In addition, nearly half of the adolescents' fathers were unskilled workers and mothers were homemakers. This may have affected the consistency of monthly income showing a higher proportion of poor families.

We have found that $33.3 \%$ of adolescents had psychosocial problems. Several studies from Nepal and India found psychosocial problems among $15-41 \%$ of adolescents [4, 7, 12-15]. Such findings suggest a vulnerability of this population to mental health problem and a need for robust school-based mental health programs.

In our study, the mental health problem among students living in a joint family were lesser than those living in a nuclear family. A similar finding was reported in central Nepal [7]. The pertinent explanation could be parents from nuclear families are mostly working and may not be able to spend quality time with their children, resulting in deprivation of proper parenting and counseling [7]. Moreover, the unconditional love that the grandparents show upon their grandchildren in joint families uplifts their self-esteem, which con- tributes to proper psychosocial development [12]. This highlights the importance of a family support for prevention of mental health problems in children.

This study revealed more mental health problems among adolescents who witnessed disputes in their family. A study done in Kathmandu reported similar findings [11]. Family dispute increases negligence of parents towards their children resulting in lesser positive interaction, which ultimately impacts negatively on adolescent development [7]. Hence, harmonious relationship among family members is one of the key factors for maintaining sound mental health in adolescents.

In the present study, all of the adolescents got punished either at home, school, or at both places. A study conducted in the western Nepal showed a significant association of mental health problems with abuse/ punishment at home [16]. Punishment is reported as a major contributor to psychosocial problems [17]. A history of punishment in our adolescents means that all are more vulnerable to mental health problems.

Socio-demographic characteristics like gender or ethnicity did not show any association with mental health status of the adolescents, similar to other studies from India $[18,19]$. A significant association of the mental health status of adolescents with their fathers' literacy has also been reported [7]. However, education was not found to be a predictor in the present study. We did not find any association between age group and mental health status. In contrast to this finding, few other studies in Nepal, India, and the US have shown a significant association of mental health problem with the age of school-going adolescents $[7,15,19,20]$.

The limitation of our study was we did not do the psychometric analysis of the translated version of the PSC-Y tool to confirm its validity and reliability.

\section{CONCLUSION}

W ental health problem was found to be common among adolescents of high schools in Dharan. Mental health status was significantly associated with nuclear family and history of a family dispute. 


\section{References}

I. Plianbangchang S. Promoting adolescent health and development in South-East Asia. Indian J Community Med. 201 I;36(4):245-6. DOI: 10.4103/0970-0218.91323

2. Adhikari RP, Upadhaya N, Pokhrel R, Suwal BR, Shrestha MP, Subedi PK. Health and social vulnerability of adolescents in Nepal.SM J Public Health Epidemiol. 2016;2(3): I032.

3. World Health organization. Mental health status of adolescents in South-East Asia: Evidence for action. New Delhi:World Health Organization, Regional Office for South-East Asia; 2017. Part I, Introduction; p.I Available from https://www.aidsdatahub.org/sites/ default/files/resource/mental-health-status-adolescents-southeast-asia-2017.pdf

4. Jian V, Singh M, Muzammil K, Singh J. Prevalence of psychological problems among adolescents in rural areas of District Muzaffar Nagar, Uttar Pradesh. Indian J Community Health. 20I4;26(3):2438. DOI: 10.18535/ijmsci/v4i2.02

5. Jellinek MS, Murphy J, Little M, Pagano ME, Comer DM, Kelleher KJ Use of the pediatric symptom checklist to screen for psychosocial problems in pediatric primary care: a national feasibility study. Arch Pediatr Adolesc Med. 1999;153(3):254-60. DOI:I0.100I/ archpedi.I53.3.254.

6. World Bank Group. Monitoring global poverty, Report of the commission on global poverty. Washington DC:World Bank; 2017 DOI: 10.1596/978-I-4648-096I-3.

7. Bista B, Thapa P, Sapkota D, Singh SB, Pokhrel PK. Psychosocial problems among adolescent students: an exploratory study in the Central Region of Nepal. Front Public Health. 2016;4:I58. DOI: I0.3389/fpubh.2016.00I58.

8. Kekkonen V, Kivimaki P,Valtonen H, Tolmunen T, Lehto S, Hintikka $\mathrm{J}$, et al. Psychosocial problems in adolescents associated with frequent health care use. Family Practice. 20I5;32(3):305-I0. DOI: I0.1093/fampra/cmu090.

9. World population review. Nepal population 2019 (demographics, maps, graphs) [Internet]. [citated on 2019 June]. Available from: https://worldpopulationreview.com/countries/nepal-population

10. Government of Nepal. Population monograph of Nepal 2014. Kathmandu: Central Bureau of Statistics; 2014.

II. Timalsina M, Kafle M,Timalsina R. Psychosocial problems among school going adolescents in Nepal. Psychiatry J. 2018;20I8:I-6. DOI: https://doi.org/I0.II55/2018/4675096

12. Singh B, Udainiya R. Self-efficacy and well-being of adolescent. J Indian Acad Appl Psychol. 2009;35(2):227-32. DOI: 10.1 I55/2018/4675096.

13. $\cup \mathrm{H}$, Arif A, H S. Assessment of mental health status among school going adolescents in North East India: A cross sectional school based survey. Asian J Psychiatr. 2017;30:I|4-7. DOI: 10.1016/j.ajp.2017.08.021

14. Koirala P, Subba R, Lopchan M. Psychosocial problems among the school children of working and non-working mothers. Journal of Chitwan Medical College. 20 I7;6(3):46. DOI: I0.3 I26/jcmc. v6i3.16699

15. Bhosale S, Singru AS, Khismatrao D. Study of psychosocial problems among adolescents. Al Ameen J Med Sci. 20I5;8(2): I50-5.

16. Banstola R. Psychosocial problem among school going adolescents in Pokhara, western Nepal. Janapriya Journal of Interdisciplinary Studies. 2017;6: I21-33. DOI: 10.3126/jjis.v6i0.19314

I7. Henderson R. Child-parent relationship and potential problems [Internet]. Patient platform limited. [updated 2016 Sept 13; cited May 29, 2019]. Available from https://patient.info/doctor/ child-parent-relationship-and-potential-problems

18. Ahamd A, Khalique N, Khan Z,Amir A. Prevalence of psychosocial problems among school going male adolescents. Indian J Community Med. 2007;32(3):2 I 9-2 I. DOI: I0.4I03/0970-02 I8.36836

19. Prakash Jyoti, Mitra AK, Prabhu HRA. Child and behavior: a school based study. Delhi Psychiatr J. 2008; I I ( ):79-82.

20. Polaha J, DaltonWT 3rd,Allen S.The prevalence of emotional and behavior problems in pediatric primary care serving rural children. J Pediatr Psychol. 201 I;36(6):652-60. DOI: 10.1093/jpepsy/ jsql 16. 